(1)

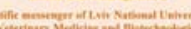

23

10iring

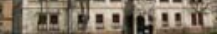

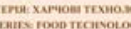

Том 21 Nis 91

2019

Науковий вісник Яьвівського національного університету ветеринарної медицини та біотехнологій імені С.3. Гжицького. Серія: Харчові технології

Scientific Messenger of Lviv National University of Veterinary Medicine and Biotechnologies.

Series: Food Technologies

ISSN 2519-268X print

https://nvlvet.com.ua/index.php/food

doi: 10.32718/nvlvet-f9107

UDC [579.864+579.873]:613.292:[ 577.11/.12:54-386]

\title{
Investigation of a bifunctional food ingredient based on a biopolymer complex of plant origin
}

\author{
M.I. Okhotska
}

Odessa National Academy of Food Technologies, Odessa, Ukraine

Article info

Received 17.01.2019

Received in revised form 15.02.2019

Accepted 18.02.2019

Odessa National Academy of Food Technologies, Kanatna Str., 112, Odesa, 65039, Ukraine.

Tel.: +38-067-706-49-07 E-mail:mariaoxota0214@ukr.net
Okhotska, M.I. (2019). Investigation of a bifunctional food ingredient based on a biopolymer complex of plant origin. Scientific Messenger of Lviv National University of Veterinary Medicine and Biotechnologies. Series: Food Technologies, 21(91), 38-42. doi: 10.32718/nvlvet-f9107

The article presents the results of studies on organoleptic, structural and mechanical, sanitary and hygienic quality indices and technological characteristics of a functional food ingredient with pro-and prebiotic properties. The technology of obtaining synbiotic is based on the process of immobilization of lactobacilli and bifidobacteria in the framework structure of the prebiotic. The raw material chosen for prebiotic production was a pulp of sugar beet, a product of processing. By physico-chemical composition of sugar beet pulp is capable of sorption of low molecular weight metabolites, toxins, radionuclides, and due to combinations of carbohydrate nature - to normalize the composition of intestinal microbiotics. In addition to using it as a "food" for microorganisms, it contributed to the protection of lactobacilli and bifidobacteria from aggressive conditions of the human digestive tract and was a protector for microorganisms, protecting them from the negative effects of the technological process - the tableting used to give the finished product a final form. The parameters of the tabletting process can affect the quantitative composition of viable microorganisms, which is associated with their deformation in an unprotected state under pressure. The amount of lactobacillus in the finished product, the tablet, was $7 \cdot 10^{8} \mathrm{CFU} / \mathrm{g}$, and the bifidobacterium was $5 \cdot 10^{8} \mathrm{CFU} / \mathrm{g}$, corresponding to a probiotic dose of not less than $1 \cdot 10^{8} \mathrm{~g} / \mathrm{cm}^{3}$. An optimal shelf-life of the product, which is 9 months at a temperature of $4 \pm 2{ }^{\circ} \mathrm{C}$, was also determined. During storage, the physiological state of the probiotic component of the functional food ingredient remains practically unchanged. The porous structure of the sugar beet biopolymer complex allows the cells to be well positioned and adsorbed on its surface. The extension of the shelf life is ensured by the carbohydrate composition of the biopolymer complex of plant origin.

Key words: biopolymer complex of sugar beet, lactobacillus, bifidobacterium, probiotic, functional nutritional ingredient.

\section{Дослідження біфункціонального харчового інгредієнта на основі біополімерного комплексу рослинного походження}

\author{
M.I. Охотська
}

Одеська національна академія харчових технологій, м. Одеса, Україна

У статті наведено результати досліджень органолептичних, структурно-механічних, санітарно-гігієнічних показників якості та технологічні характеристики функиіонального харчового інгредієнта з про- та пребіотичними властивостями. Технологія отримання синбіотика базується на прочесі іммобілізаџї лактобацил та біфідобактерій в каркасній структурі пребіотика. Сировиною, яку обрали для отримання пребіотика, став жом иукрового буряку, вторинний продукт переробки. За фізико-хімічним складом жом иукрового буряку здатний до сорбиї низькомолекулярних метаболітів, токсинів, радіонуклідів, а за рахунок сполучень вуглеводної природи - до нормалізачії складу мікробіоти кишечнику. Окрім використання його як “їжі” для мікроорганізмів, він сприяв захисту лактобацил та біфідобактерій від агресивних умов шлунково-кишкового тракту людини та був протектором для мікроорганізмів, оберігаючи їх також від негативного впливу технологічного процесу - таблетування, застосованого для надання готовому продукту кінцевого вигляду. Параметри процесу таблетування можуть позначитись на кількісному складі життєздатних мікроорганізмів, щзо пов'язано з їхньою деформацією в незахищеному стані під тиском. Кількість лактобацил у 
готовому продукті - таблетиі - становила $7 \cdot 10^{8} \mathrm{KУО/2,} \mathrm{а} \mathrm{біфідобактерій} \mathrm{-} \mathrm{5·10}{ }^{8}$ КУО/2, щүо відповідає пробіотичній дозі: не менш ніж $1 \cdot 10^{8}$ г см. $2{ }^{\circ} \mathrm{C}$. Під час зберігання фізіологічний стан пробіотичної складової функиіонального харчового інгредієнта залишається практично незмінним. Пориста структура біополімерного комплексу цукрового буряку дозволяє клітинам добре розташуватись та адсорбуватись на його поверхні. Пролонгаџію терміну зберігання забезпечує вуглеводний склад біополімерного комплексу рослинного походження.

Ключові слова: біополімерний комплекс иукрового буряку (БПКЦБ), лактобацили, біфідобактерії, пробіотик, функціональний харчовий інгредієнт (ФXI).

\section{Вступ}

Суттєвим недоліком в житті більшості сучасного населення України є харчові звички, орієнтовані на їжу швидкого приготування, відсутність достатньої кількості свіжих овочів та фруктів, кисломолочних продуктів, а також споживання великої кількості продуктів 3 підвищеним вмістом цукру. Також відомо, що користь від використання та дії медичних препаратів під час лікування призводить не тільки до поліпшення самопочуття людини, а й до небезпечних наслідків. Доведено, що дестабілізуючий вплив антимікробних хіміопрепаратів на організм передовсім викликає мікробіологічні порушення, які здебільшого мають стійкий характер. Після терапії зазвичай спостерігається повільне та неповне відновлення кількісних показників мікробіоти, зниження іiі видового різноманіття призводить до необхідності у їі корекції. Тому концепція поліпшення стану здоров'я громадян України та зниження темпів їхнього старіння повинна передбачити введення у раціон харчування продуктів 3 функціональним навантаженням. Окремою, стратегічно важливою ланкою у поліпшенні фізіологічного статусу людини є розробка продуктів, які здатні корегувати, а в деяких випадках повністю змінювати біотоп людини.

Розробка технологій отримання функціональних харчових інгредієнтів (ФХІ) нешкідливих, природного походження, екологічно безпечних, чистих, які не мають протипоказань для застосування в харчовій промисловості та містять компоненти, здатні позитивно впливати на загальний стан здоров'я людини, $є$ одним 3 головних пріоритетів у напрямку формування не тільки фізіологічно здорових представників нації, а й екосвідомості у майбутнього покоління.

Для створення таких функціонально навантажених харчових продуктів доцільно долучати біологічно активні речовини або мікроорганізми з пробіотичною активністю. Останні спроможні поліпшити природний шлях регуляції імунних реакцій в організмі, що обумовлено їх природними властивостями (Belkaid \& Timothy, 2014; Vandeputte et al., 2017).

При виборі сировини для отримання цілісного функціонального харчового продукту потрібно ретельно спрогнозувати фізіологічний ефект від його застосування. Під час розробки нового біфункціонального харчового інгредієнта 3 пробіотичними мікроорганізмами варто знати кількісний склад та таксонометричні характеристики біотопу людини. Потреба в певних видах мікроорганізмів обумовлена сукупністю властивостей їх фенотипу, а також біологічно активних продуктів їхнього метаболізму, що надалі визначають спектр та виразність профілактичної ефективності конкретної пробіотичної складової (Kaliuzhyn et al., 2016). Пробіотичні мікроорганізми у достатній кількості в організмі людини та у правильно підібраному синергізмі не конкурують один з одним, а спрямовують свою дію на представників патогенної мікробіоти, не даючи їм змоги колонізувати епітелій слизової оболонки людини, і таким чином впевнено конкурувати саме $з$ ними за свою екологічну нішу (Belkaid \& Timothy, 2014).

Біфідобактеріям та лактобацилам властиве забезпечення сигналів толерантності до власних та чужорідних антигенів і таким чином - зниження вірогідності розвитку алергічних та аутоіммуних реакцій. Завдяки застосуванню бактерій-пробіотиків мінімізується ризик надмірного навантаження та стимуляції імунітету (Kaliuzhyn et al., 2016; Musiy et al., 2017; Thomas et al., 2017).

Варто також зазначити, що перевага, яка надається комплексним препаратам чи продуктам, до яких додають, наприклад, пребіотичну складову, пояснюється здатністю пребіотика забезпечити оптимальні умови для реалізації імуномоделюючої дії пробіотичних штамів, сприяти збільшенню кількісного складу корисних представників біотопу людини в якості “іжі” та проявити стосовно до мікроорганізмів протекторні властивості, зберігаючи біологічний ефект від пробіотичної складової ФХІ.

Актуальність проблеми. Аналіз інформаційних джерел виявив численні публікації в напрямку наших досліджень, що підтверджує актуальність обраної нами тематики - створення біфункціонального інгредієнта харчування, дія якого спрямована на поліпшення мікробного статусу людини, а також зміцнення його імунітету.

Наукові дослідження було зорієнтовано на подальше визначення показників якості та терміну зберігання ФХІ з про- та пребіотичними властивостями.

Мета $i$ завдання дослідження. 3 урахуванням існуючого дисбалансу в харчових звичках сучасної людини виникає необхідність розширення асортименту продуктів харчування, які функціонально спрямовані на поліпшення якісного та кількісного складу іiі мікробіоти.

Метою наукової роботи стало дослідження показників якості отриманого БПКЦБ та ФXI 3 про- та пребіотичними властивостями, створеного на його основі, спроможного за своїм вуглеводним та мікробіологічним складом позитивно вплинути на біотоп та перистальтику кишківника людини, а також встановлення терміну придатності ФХІ з про- та пребіотичними властивостями.

Досягнення сформульованої мети можливе через вирішення таких завдань: визначення органолептич- 
них, структурно-механічних та мікробіологічних показників якості БПКЦБ - матриксу для лактобацил та біфідобактерій; визначення органолептичних, мікробіологічних та санітарно-гігієнічних показників якосTi, а також технологічних характеристик ФXI з про- та пребіотичними властивостями; встановлення терміну зберігання ФХІ з про- та пребіотичними властивостями.

\section{Матеріал і методи досліджень}

Сировиною для пребіотичної складової став жом цукрового буряку. Доцільність його використання в якості харчового компоненту, здатного забезпечити протекторні властивості стосовно до мікроорганізмів та добову потребу людини у “складних” вуглеводах була доведена його фізико-хімічним складом (Kapreliants \& Hotsulenko, 2007). Але у нативному стані він не відповідав вимогам до харчового продукту та не був придатний за своєю структурою до наступного етапу використання - іммобілізації мікроорганізмів. Тому була проведена його хімічна модифікація, яка передбачала декілька етапів: гідротермічну обробку жому гідроксидом натрію на протязі 20-30 хвилин за температури $60-65^{\circ} \mathrm{C}$, а далі водним розчином пероксидводню 1,5-2 години за температури 60-65 ${ }^{\circ} \mathrm{C}$ (Kapreliants \& Hotsulenko, 2007).

У пробіотичну складову увійшли класичні представники кишкової мікробіоти людини, здатні до симбіозу між собою - Lactobacillus acidophilus, Bifidobacterium adolescentis та B.bifidum.

Поєднання мікроорганізмів та носія відбулося методом іммобілізації, який базується на фізичній адсорбції клітин мікроорганізмів на пористій структурі БПКЦБ.

Першим об'єктом досліджень було обрано органолептичні, структурно-механічні властивості носія БПКЦБ, далі досліджували показники якості та технологічні характеристики отриманого шляхом іммобілізації, ліофілізації та таблетування ФХІ з про- та пребіотичними складовими. Також встановлювали термін зберігання синбіотика.

Для здійснення визначених завдань використовували сучасні та загальновизнані методи досліджень, якими визначали: органолептичні показники; структурно-механічні показники; технологічні характеристики; санітарно-гігієнічні показники - ГОСТ 3017896; кількість лактобацил в 1 г - ГОСТ 10444.11; кількість біфідобактерій в 1 г - [МУК 4.2.999-00]; термін зберігання таблетованного ФХІ.

\section{Результати та їх обговорення}

У нативному стані жом цукрового буряку (ЖЦБ) потребував попереднього удосконалення та змін його фізико-хімічних властивостей у зв'язку з невідповідністю усім вимогам до харчового інгредієнту. Після модифікації шляхом лужно-пероксидводневої обробки було отримано біополімерний комплекс та досліджено його органолептичні, структурно-механічні та мікробіологічні показники якості. Проводилось порівняння з немодифікованою сировиною (табл. 1).

\section{Таблиця 1}

Характеристика органолептичних показників ЖЦБ та БПКЦБ

\begin{tabular}{ccc}
\hline $\begin{array}{c}\text { Назва } \\
\text { показника }\end{array}$ & ЖцБ & БПКЦБ \\
\hline Колір & Темно-сірий & Світло-кремовий \\
Смак & Специфічний, & Солодкуватий \\
& буряковий & \\
Запах & Спецфічний, без & Чистий, без \\
& затлог, пліснявого & запахів \\
\hline
\end{tabular}

Результати досліджень вказують на поліпшення органолептики біополімерного комплексу за усіма показниками.

Для подальшого використання БПКЦБ як матрикса для клітин необхідно було дослідити його структурно-механічні показники. БПКЦБ заздалегідь подрібнювали до діаметру часток 0,25-0,5 мм. Використання саме цієї фракції БПКЦБ обгрунтовано результатами досліджень сумісного культивування лактобацил та біфідобактерій на модифікованому носії: на частках вказаного розміру відбулося найкраще розташування та адсорбція клітин пробіотиків (Kapreliants \& Hotsulenko, 2008).

Структурно-механічні показники БПКЦБ наведено у табл. 2.

\section{Таблиця 2}

Структурно-механічні показники БПКЦБ

\begin{tabular}{lc}
\hline \multicolumn{1}{c}{ Назва показника } & Характеристика \\
\hline Об’ємна маса, г/л & 391,6 \\
Кут природного укосу, град & 47 \\
Сипкість, см/с & 4,46 \\
\hline
\end{tabular}

Отриманні результати підтверджують доцільність використання БПКЦБ якості матриксу для мікроорганізмів на основі відповідності структурно-механічним показникам.

Надалі БПКЦБ досліджували за мікробіологічними показниками, які обумовлюють термін зберігання готового продукту, a згодом i функціональнофізіологічні властивості БПКЦБ. Результати досліджень наведені в табл. 3.

Таблиця 3

Мікробіологічні показники БПКЦБ

\begin{tabular}{|c|c|c|}
\hline Назва показника & $\begin{array}{c}\text { Норма } \\
\text { Сан ПиН } \\
2.3 .2 .1078-01\end{array}$ & $\begin{array}{c}\text { Вміст } \\
\text { у БПКЦБ }\end{array}$ \\
\hline $\begin{array}{l}\text { КМАФАнМ, } \\
\text { КУО в 1г продукту }\end{array}$ & не більш $5 \cdot 10^{3}$ & $5 \cdot 10^{2}$ \\
\hline $\begin{array}{l}\text { Плісеневі гриби, } \\
\text { КУО в 1г продукту }\end{array}$ & не допускаються & відсутні \\
\hline $\begin{array}{l}\text { Патогенні мікроорганізми, } \\
\text { у тому числі сальмонели в } \\
10 \text { г продукту }\end{array}$ & не допускаються & відсутні \\
\hline БГКП в 1 г продукту & не допускаються & відсутні \\
\hline
\end{tabular}


Така характеристика свідчить про те, що БПКЦБ відповідає санітарно-гігієнічним вимогам до доброякісних продуктів харчування [Сан ПиН 2.3.2.1078-01].

У подальшому проводили іммобілізацію лактобацил та біфідобактерій на БПКЦБ. Процес відбувався в два етапи: насамперед поживне середовище (стерильне знежирене молоко) зі стерильним носієм інокулювали суспензією клітин Bifidobacterium adolescentis, $B$. bifidum. Доза стартової культури, яка містить $1 \cdot 10^{8} \mathrm{KУО} / \mathrm{cm}^{3}$ становила $5 \%$, культивування тривало 24 години за температури $38 \pm 1 \mathrm{C}$, після цього до суміші додавали дозу Lactobacillus acidophilus - 5 \% із вмістом клітин $1 \cdot 10^{8} \mathrm{KУO} / \mathrm{cm}^{3}$. Сумісна іммобілізація клітин проводилась ще 24 години за температури $38 \pm$ $1{ }^{\circ} \mathrm{C}$ (Kapreliants \& Hotsulenko, 2007).

Для збереження клітин у їхньому фізіологічноактивному стані в готовому продукті було обрано ліофілізацію. Варто зауважити, що ліофілізована біомаса мікроорганізмів володіє значно більшим терміном придатності та довше зберігає свої функціональні властивості порівняно з пробіотичними мікроорганізмами в рідкому стані. У препараті, який сухий за своєю консистенцією, клітини перебували в анабіозі, і їм необхідно понад 8 годин для переходу в активний стан, в рідкому стані клітини є біологічно активними відразу. Але за час перетравлення їжі більша їх частина може природним шляхом елімінуватися 3 кишківника (Rajilić-Stojanović \& de Vos, 2014).

Таблетована форма препарату володіє технологічними перевагами порівняно з продуктами в сипучому стані: вони не злежуються, мають довгий термін придатності, компактні, зручні при транспортуванні, гігієнічні, дозволяють здійснювати точне дозування продукту.

В процесі таблетування використовують допоміжні матеріали для надання препарату необхідної форми для споживання, але для отримання ФХІ на основі БПКЦБ з певними параметричними характеристиками необхідність у них відсутня. В нашому випадку як компонент для зв'язування виступають власні пектинові речовини та целюлоза БПКЦБ. Також завдяки тому, що іммобілізація клітин проводилася за наявності молочного середовища, залишки сухого молока після ліофілізації добре скріплюють між собою частинки БПКЦБ з іммобілізованими в їх структурі клітинами. Органолептичні та структурно-механічні показники якості продукту після ліофілізації та таблетування наведено у таблицях 4, 5 .

\section{Таблиця 4}

Характеристика органолептичних показників ФXI 3 про- та пребіотичними властивостями

\begin{tabular}{cc}
\hline Показник & Характеристика \\
\hline Зовнішній & Таблетка плоскоциліндричної форми, \\
вигляд & цільні краї \\
Смак та запах & Кисломолочний \\
Колір & Світло-кремовий \\
Домішки & Відсутні \\
\hline
\end{tabular}

Матеріали табл. 4 свідчать про прийнятні органолептичні показники одержаного ФХІ. Надалі встанов- лювали технологічні характеристики таблетованної форми ФХІ (табл. 5).

\section{Таблиця 5}

Технологічні характеристики якості ФХІ 3 про- та пребіотичним властивостями $(\mathrm{n}=5, \mathrm{P} \leq 0,05)$

\begin{tabular}{lc}
\hline \multicolumn{1}{c}{ Назва показника } & Характеристика \\
\hline Форма & Плоскоциліндрична \\
Діаметр, мм & $20,00 \pm 0,30$ \\
Висота, мм & $5,00 \pm 0,25$ \\
Маса, Г & $1,5 \pm 0,15$ \\
Щільність, мм & $930 \pm 0,15$ \\
Здатність до стирання, \% & $95 \pm 0,75$ \\
Ударна міцність, кг & $0,5 \pm 0,025$ \\
Здатність до розпадання у воді, & $2 \pm 0,05$ \\
хвилин & \\
\hline
\end{tabular}

На підставі отриманих даних встановлено, що таблетка спроможна легко розпадатися, що необхідно під час іiі транзиту до нижніх відділів кишківника. Було також визначено санітарно-гігієнічні показники якості ФХІ $з$ про- та пребіотичним властивостями для підтвердження безпечності отриманого продукту (табл. 6).

\section{Таблиця 6}

Санітарно-гігієнічні показники якості ФХІ 3 про- та пребіотичними властивостями $(\mathrm{n}=5, \mathrm{P} \leq 0,05)$

\begin{tabular}{lcc}
\hline \multicolumn{1}{c}{ Назва показника } & $\begin{array}{c}\text { Допустимі } \\
\text { рівні, мг/кг, не } \\
\text { більш }\end{array}$ & $\begin{array}{c}\text { Вміст, } \\
\text { мг/кг }\end{array}$ \\
\hline Токсичні елементи: & & \\
Свинець & 1,0 & 0,763 \\
Кадмій & 0,05 & 0,048 \\
Ртуть & 0,02 & 0,011 \\
Арсен & 1,0 & 0,32 \\
Мідь & 25,0 & 2,07 \\
Цинк & 50,0 & 15,8 \\
Пестициди: & 0,005 & 0,0024 \\
Гексахлоран ГХЦГ & & \\
Гама ізомер & & 0,0061 \\
Фостоксин & 0,01 & 0,0036 \\
ДДТ & 0,005 & \\
\hline
\end{tabular}

Для подальших досліджень і впровадження отриманого продукту у виробництво необхідно було визначити умови його зберігання. У будь-якому харчовому продукті відбуваються біохімічні реакції, які впливають на зміни його властивостей, фізіологічні діï, ефект від яких прогнозується при розробці технології. Загальновідомо, що продукти 3 пробіотичною складовою втрачають свою активність під час зберігання, тому необхідно контролювати та провести дослідження змін цього показника протягом усього терміну зберігання ФХІ з про- та пребіотичними властивостями та встановити кінцевий термін придатності продукту. Дослідження проводились протягом 9 місяців. Відібрані проби зразків, які аналізували упаковували в щільну блістерну упаковку та зберігали за температури $4 \pm 2{ }^{\circ} \mathrm{C}$ (табл. 7). 


\section{Таблиця 7}

Зміни фізіологічного активності пробіотичної складової ФХІ з про- та пребіотичними властивостями під час зберігання

\begin{tabular}{lcccc}
\hline \multicolumn{1}{c}{$\begin{array}{c}\text { Кількість } \\
\text { життєздатних } \\
\text { клітин }\end{array}$} & \multicolumn{4}{c}{ Термін зберігання, місяці } \\
\cline { 2 - 5 } & 1 & 3 & 6 & 9 \\
\hline $\begin{array}{l}\text { Лактобацил, } \\
\text { КУО/г }\end{array}$ & $7 \cdot 10^{8}$ & $5 \cdot 10^{8}$ & $3 \cdot 10^{8}$ & $2 \cdot 10^{8}$ \\
$\begin{array}{l}\text { Біфідобактерій, } \\
\text { КУО/г }\end{array}$ & $5 \cdot 10^{8}$ & $3 \cdot 10^{8}$ & $3 \cdot 10^{8}$ & $2 \cdot 10^{8}$ \\
\hline
\end{tabular}

Виявлена висока фізіологічна активність Lactobacillus acidophilus та Bifidobacterium adolescentis, B.bifidum протягом 9 місяців зберігання. На основі отриманих результатів умовами зберігання ФXI з прота пребіотичними властивостями було обрано 9 місяців за температури $4 \pm 2{ }^{\circ} \mathrm{C}$.

\section{Висновки}

Аналіз отриманих результатів характеризує ФХІ з про- та пребіотичними компонентами як продукт харчового функціонального спрямування, в якому пробіотична складова захищена матриксом носія рослинного походження. Протекторні властивості рослинного носія проявляються не тільки у резистентності клітин до технологічних режимів, а й під час зберігання продукту та суттєво подовжує цей термін який становить 9 місяців за температури $4 \pm 2{ }^{\circ} \mathrm{C}$.

Перспективи подальших досліджень. Подальші дослідження будуть спрямовані на розробку нових методів модифікації рослинної сировини для отримання ФХІ на їх основі.

\section{References}

Belkaid, Y., \& Timothy, W. (2014). Hand Role of the Microbiota in Immunity and Inflammation. Cell, 157(1), 121-141. doi: 10.1016/j.cell. 2014.03.011.

Kaliuzhyn, O.V., Afanasiev, S.S., \& Bykov, A.S. (2016). Peroralnye probiotyki kak stimuliatory protivoinfiektsionnoho immunnoho otvieta V riespieratornom traktie. Tierapievticheskiy arkhiv, 88(5), 118-124 (in Russian).

Kapreliants, L.V., \& Hotsulenko, M.I. (2007). Sposib oderzhannia kharchovoi dobavky $\mathrm{z}$ adsorbovanoiu zdatnistiu. Patent № 26442. 2007 Sep. 25 (in Ukrainian).

Kapreliants, L.V., Hotsulenko, M.I. (2008). Sposib oderzhannia synbiotychnoi biolohichno aktyvnoi dobavky. Patent № 31932. 2008 Apr. 25 (in Ukrainian).

Musiy, L., Tsisaryk, O., Slyvka, I., Mykhaylytska, O., \& Gutyj, B. (2017). Research into probiotic properties of cultured butter during storing. Eastern-European Journal of Enterprise Technologies, 3, 11(87), 31-36. doi: 10.15587/1729-4061.2017.103539.

Rajilić-Stojanović, M., \& de Vos, W.M. (2014). The first 1000 cultured species of the human gastrointestinal microbiota. FEMS Microbiol Rev, 38(5), 996-1047. doi: 10.1111/1574-6976.12075.

Thomas, S., Izard, J., Walsh, E., Batich, K., Chongsathidkiet, P., Clarke, G., Sela, D.A., Muller, A.J., Mullin, J.M., Albert, K., Gilligan, J.P., DiGuilio, K., Dilbarova, R., Alexander, W., \& Prendergast, G.C. (2017). The Host Microbiome Regulates and Maintains Human Health: A Primer and Perspective for Non-Microbiologists. Cancer Res, 77(8), 17831812. doi: 10.1158/0008-5472.CAN-16-2929.

Vandeputte, D., Kathagen, G., D'hoe, K., Vieira-Silva, S., Valles-Colomer, M., Sabino, J., Wang, J., Tito, R.Y., De Commer, L., Darzi, Y., Vermeire, S., Falony, G., \& Raes, J. (2017). Quantitative microbiome profiling links gut community variation to microbial load. Nature, 551(7681), 507-511. doi: 10.1038/nature24460. 